\title{
Characteristics of Work Accident among Tobacco Farmers in Indonesia
}

\section{Ledya Anggriani Hariyanto ${ }^{1 *}$, Retno Purwandari2 ${ }^{2}$ Alfid Tri Afandi ${ }^{3}$}

${ }^{1}$ Faculty of Nursing, Universitas Jember, Indonesia; ledyaanggriani@gmail.com (Corresponding Author)

${ }^{2,3}$ Fundamental of Nursing Department, Faculty of Nursing, Universitas Jember, Indonesia

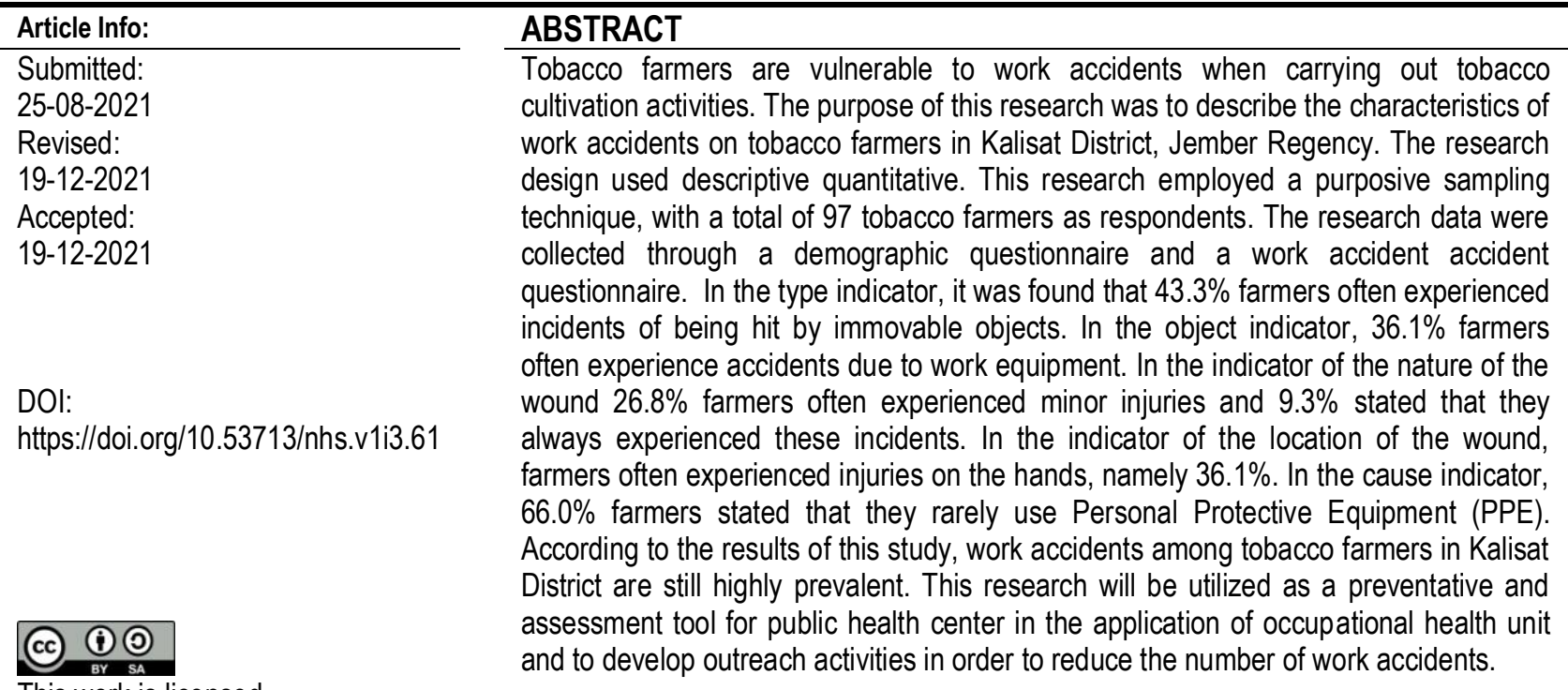

This work is licensed

under CC BY-SA License.

Keywords: agricultural; tobacco farmer; work accidents; descriptive

\section{INTRODUCTION}

Indonesia is an agrarian country where most of the population works in agriculture. Indonesia is the third largest tobacco producer in Asia with a land area of 186 thousand $\mathrm{Ha}$. The contribution of tobacco in East Java reaches $27 \%$ of the total agricultural output. Tobacco producing districts in East Java include Madura, Bojonegoro, Lamongan, Lumajang, Bondowoso, Jember, and Situbondo (Septiani, 2019). Jember regency is known as one of the national food barns. In the horticultural subsector, tobacco commodities are the largest contributor to the export value of Jember Regency which has agricultural output of $71.29 \%$. Subdistrict in Jember which is a tobacco producing area in the first place is Kalisat Subdistrict. Kalisat district is among the sub-districts that have the highest production and the largest area is 2,350 Ha. The majority of the population in Kalisat Subdistrict has a livelihood as tobacco farmers (Septiani, 2019).

Tobacco farmers are individuals who are members of agricultural business groups engaged in the cultivation of the agricultural sector in the form of tobacco. To produce the best tobacco plants, the tobacco treatment process requires special and detailed treatment. The tobacco planting period is about four months with treatment in the form of daily watering, embroidery of tobacco seedlings that is done timelessly one week after planting, and weeding every three weeks (Markus et al., 2015). When doing tobacco cultivation activities, farmers are vulnerable to work accidents (Intani, 2013). Work accidents can be affected by several things, namely, work tools, machines, materials, and the workplace. Therefore, the use of PPE is a mandatory thing in the agricultural sector because in this sector workers must spray pesticides, be directly exposed to crops, and exposed directly to sunlight (Nanda, 2012). According to Zhang et al. (2011)'s research, up to 1 million people are poisoned each year as a result of pesticide use.

Research conducted by Widayati (2014), said that tobacco farming activities provide a large and increased workload that causes them to continue their work at night. Based on this, research conducted by Jannah (2018) that tobacco farmers have high working hours of 7 hours / day to carry out the process of planting, irrigation, maintenance, embroidery, fertilization, weeding, pruning, pest control, harvesting, until post-harvest. 
Based on the phenomenon that has been explained about the magnitude of the risk of work accidents owned by tobacco farmers, researchers need to review the characteristics of work accidents in tobacco farmers in Kalisat District of Jember Regency.

\section{METHOD}

A descriptive quantitative method were used in this study. The population of this study is tobacco farmers in Kalisat Subdistrict with a sample of 97 respondents. Researchers used the purposive sampling technique. Kalisat district consists of 12 villages and is carried out purposive sampling technique in 6 Kalisat villages. Respondents' retrievals are done using proportions. A total of 6 research villages were calculated by proportionate random sampling of each village to determine the number of respondents for the study sample in each village. The determination of respondents based on consideration of research criteria that meet the criteria of inclusion and exclusion in the study. The study was conducted from June to July 2021. The data collection tool in this study use a questionnaire sheet characteristic of work accidents from Rizani Noor, et al (2018) research. Data analysis was performed using univariate analysis, only describing the frequency and presentation of work accidents tobacco farmers in Kalisat District, Jember Regency. The ethics of this research was carried out with an ethical feasibility test at the Faculty of Nursing, University of Jember No. 102/UN25.1.14/KEPK/2021.

\section{RESULT}

\section{Characteristics of Respondents}

Table 1. Distribution of respondents based on the age of tobacco farmers in Kalisat District Jember Regency

\begin{tabular}{ccc}
\hline Characteristics & Median & Min-max \\
\hline Age & 52,00 & $35-70$ \\
\hline
\end{tabular}

Based on table 1, it can be known that the characteristic results of tobacco farmers in Kalisat District of Jember Regency, namely the middle age value of respondents 52.00 years. The minimum age of respondents is 35 years and a maximum of 70 years

Table 2. Distribution of respondents based on gender, last education, and length of work on tobacco farmers in Kalisat District of Jember Regency ( $n=100)$

\begin{tabular}{lcc}
\hline \multicolumn{1}{c}{ Characteristics } & Frequency & Percentage \\
\hline Gender & & \\
Male & 82 & 84.5 \\
Female & 15 & 15.5 \\
\hline Total & 97 & 100.0 \\
\hline Education & & \\
Not attending school & 26 & 26.8 \\
Elementary School & 61 & 62.9 \\
Junior High School & 8 & 8.2 \\
Senior High School & 2 & 2.1 \\
\hline Total & 97 & 100.0 \\
\hline Length of work & & \\
<10 years & 6 & 6.2 \\
10-19 years & 32 & 33.0 \\
$>20$ years & 59 & 60.8 \\
\hline Total & 97 & 100.0 \\
\hline
\end{tabular}

Based on table 2, it can be known that the Characteristics of tobacco farmers in Kalisat District Jember Regency namely the majority of $82(84.5 \%)$ respondent are male. The last education of the most respondents was the end of elementary school as many as $61(62.9 \%)$ respondents. The length of work in farmers showed more than half who worked as farmers for $>20$ years, which was $59(60.8 \%)$ respondents. 
Table 3. Distribution of frequency indicators of types work accidents in tobacco farmers in Kalisat District Jember Regency

\begin{tabular}{clcccccccc}
\hline \multirow{2}{*}{ No } & \multirow{2}{*}{ Type of Accident } & \multicolumn{2}{c}{ Always } & \multicolumn{2}{c}{ Often } & \multicolumn{2}{c}{ Sometimes } & \multicolumn{2}{c}{ Never } \\
\cline { 2 - 10 } & $\mathrm{f}$ & $(\%)$ & $\mathrm{f}$ & $(\%)$ & $\mathrm{f}$ & $(\%)$ & $\mathrm{f}$ & $(\%)$ \\
\hline 1 & Fall & 0 & $(0.0)$ & 24 & $(24.7)$ & 52 & $(53.6)$ & 21 & $(21.6)$ \\
\hline 2 & Slip & 0 & $(0.0)$ & 19 & $(19.6)$ & 57 & $(58.8)$ & 21 & $(21.6)$ \\
\hline 3 & Hit by a falling object & 0 & $(0.0)$ & 19 & $(19.6)$ & 53 & $(54.6)$ & 25 & $25.8)$ \\
\hline 4 & Hit by an immovable object & 3 & $(3.1)$ & 42 & $(43.3)$ & 38 & $(39.2)$ & 14 & $(14.4)$ \\
\hline 5 & Stuck between two things & 0 & $(0.0)$ & 7 & $(7.2)$ & 46 & $(47.4)$ & 44 & $(45.4)$ \\
\hline 6 & Electrocuted & 0 & $(0.0)$ & 0 & $(0.0)$ & 6 & $(6.2)$ & 91 & $(93.8)$ \\
\hline
\end{tabular}

Based on table 3, shows that from the 6 items of indicator questions, at number 6,91 (93.9\%) of respondents never experienced electrocution. A total of $57(58.8 \%)$ respondents to item number 2 stated that they are sometimes slip while working on land. It is also known in item number 4 states that as many as $42(43.3 \%)$ respondents are often hit by immovable objects and a number of $3(3.1 \%)$ respondents stated that they are always hit by immovable objects.

\section{Characteristics of Work Accidents by Object}

Table 4. Distribution of frequency object indicators in tobacco farmers work accidents in Kalisat District Jember Regency

\begin{tabular}{llcccccccc}
\hline \multirow{2}{*}{ No Object } & \multicolumn{2}{c}{ Always } & \multicolumn{2}{c}{ Often } & \multicolumn{2}{c}{ Sometimes } & \multicolumn{2}{c}{ Never } \\
\cline { 3 - 10 } & \multirow{2}{*}{ Machine } & $f$ & $(\%)$ & $\mathrm{f}$ & $(\%)$ & $\mathrm{f}$ & $(\%)$ & $\mathrm{f}$ & $(\%)$ \\
\hline 1 & 0 & $(0.0)$ & 0 & $(0.0)$ & 18 & $(18.6)$ & 79 & $(81.4)$ \\
\hline 2 & Conveyance & 0 & $(0.0)$ & 0 & $(0.0)$ & 12 & $(12.4)$ & 85 & $(87.6)$ \\
\hline 3 & Work equipment & 2 & $(2.1)$ & 35 & $(36.1)$ & 49 & $(50.5)$ & 11 & $(11.3)$ \\
\hline 4 & Materials and radiation & 0 & $(0.0)$ & 1 & $(1.0)$ & 21 & $(21.6)$ & 75 & $(77.3)$ \\
\hline 5 & Animal & 0 & $(0.0)$ & 9 & $(9.3)$ & 52 & $(53.6)$ & 36 & $(37.1)$ \\
\hline
\end{tabular}

Based on table 4, shows that from the 5 items of indicator questions, at number 2, as many as $85(87.6 \%)$ respondents never had an accident by conveyance. A total of $52(53.6 \%)$ respondents to item number 5 stated that they sometimes have accidents due to animals. It is also known in item number 3 states that as many as $35(36.1 \%)$ respondents often have accidents due to work equipment and a number of $2(2.1 \%)$ respondents stated that they always have accidents due to work equipment.

\section{Characteristics of Work Accidents by Nature of Wound}

Table 5. Distribution of frequency of the indicator of the nature of the wound in the work accident of tobacco farmers in Kalisat District Jember Regency

\begin{tabular}{llcccccccc}
\hline \multirow{2}{*}{ No } & \multirow{2}{*}{ Nature of wound } & \multicolumn{2}{c}{ Always } & \multicolumn{2}{c}{ Often } & \multicolumn{2}{c}{ Sometimes } & \multicolumn{2}{c}{ Never } \\
\cline { 2 - 10 } & $\mathrm{f}$ & $(\%)$ & $\mathrm{f}$ & $(\%)$ & $\mathrm{f}$ & $(\%)$ & $\mathrm{f}$ & $(\%)$ \\
\hline 1 & Fracture & 0 & $(0.0)$ & 0 & $(0.0)$ & 0 & $(0.0)$ & 97 & $(100.0)$ \\
\hline 2 & Sprain & 0 & $(0.0)$ & 0 & $(0.0)$ & 40 & $(41.2)$ & 57 & $(58.8)$ \\
\hline 3 & Concussion & 0 & $(0.0)$ & 0 & $(0.0)$ & 0 & $(0.0)$ & 97 & $(100.0)$ \\
\hline 4 & Amputation and enukleration & 0 & $(0.0)$ & 0 & $(0.0)$ & 0 & $(0.0)$ & 97 & $(100.0)$ \\
\hline 5 & Minor injuries & 9 & $(9.3)$ & 26 & $(26.8)$ & 50 & $(51.5)$ & 12 & $(12.4)$ \\
\hline 6 & Bruised or crushed & 0 & $(0.0)$ & 0 & $(0.0)$ & 12 & $(12.4)$ & 85 & $(87.6)$ \\
\hline 7 & Burn & 0 & $(0.0)$ & 0 & $(0.0)$ & 0 & $(0.0)$ & 97 & $(100.0)$ \\
\hline 8 & Electric current & 0 & $(0.0)$ & 0 & $(0.0)$ & 5 & $(5.2)$ & 92 & $(94.8)$ \\
\hline
\end{tabular}


Based on table 5, shows that from the 8 items of indicator question, at numbers 1, 3, and 7, $97(100 \%)$ of respondents never had a work accident with fractures, concussion, and burns. A total of $40(41.2 \%)$ respondents in item number 2 stated that they sometimes have a sprained work accident or sprain during work. Question number 5 is a question that has more answers very often compared to other items, namely as many as $26(26.8 \%)$ respondents said they often find minor injuries on their bodies due to activities carried out. It is also known on the item that as many as 9 $(9.3 \%)$ of respondents always suffered minor injuries.

\section{Characteristics of Work Accidents by Wound Location}

Table 6. Distribution of frequency indicator of the wound location in the work accident of tobacco farmers in Kalisat District Jember Regency

\begin{tabular}{cccccccccc}
\hline \multirow{2}{*}{ No } & \multirow{2}{*}{ Wound location } & \multicolumn{2}{c}{ Always } & \multicolumn{2}{c}{ Often } & \multicolumn{2}{c}{ Sometimes } & \multicolumn{2}{c}{ Never } \\
\cline { 2 - 9 } & $\mathrm{f}$ & $(\%)$ & $\mathrm{f}$ & $(\%)$ & $\mathrm{f}$ & $(\%)$ & $\mathrm{f}$ & $(\%)$ \\
\hline 1 & Head & 0 & $(0.0)$ & 0 & $(0.0)$ & 2 & $(2.1)$ & 95 & $(97.9)$ \\
\hline 2 & Neck & 0 & $(0.0)$ & 0 & $(0.0)$ & 6 & $(6.2)$ & 91 & $(93.8)$ \\
\hline 3 & Body & 0 & $(0.0)$ & 0 & $(0.0)$ & 23 & $(23.7)$ & 74 & $(76.3)$ \\
\hline 4 & Hand & 0 & $(0.0)$ & 35 & $(36.1)$ & 41 & $(42.3)$ & 21 & $(21.6)$ \\
\hline 5 & Leg & 0 & $(0.0)$ & 0 & $(0.0)$ & 53 & $(54.6)$ & 44 & $(45.4)$ \\
\hline
\end{tabular}

Based on table 6, shows that from the 5 items of indicator questions, at number 1, $95(97.9 \%)$ of respondents never experienced a work accident injury to the head. A total of $53(54.6 \%)$ respondents to item number 5 stated that they sometimes experience work accident injuries in the legs while working. Question number 4 is a question that has more answers very often compared to other items, namely as many as $35(36.1 \%)$ respondents said they often find wounds on their hands while on the move.

\section{Characteristics of Work Accidents by Cause of Accident}

Table 7. Distribution of frequency of causative indicators in tobacco farmers' work accidents in Kalisat District of Jember Regency

\begin{tabular}{clcccccccc}
\hline \multirow{2}{*}{ No Cause of Accident } & \multicolumn{2}{c}{ Always } & \multicolumn{2}{c}{ Often } & \multicolumn{3}{c}{ Sometimes } & \multicolumn{3}{c}{ Never } \\
\cline { 3 - 9 } & & $f$ & $(\%)$ & $f$ & $(\%)$ & $f$ & $(\%)$ & $f$ & $(\%)$ \\
\hline 1 & Wearing self-protection equipment & 11 & $(11.3)$ & 16 & $(16.5)$ & 64 & $(66.0)$ & 6 & $(6.2)$ \\
\hline 2 & Material usage error & 0 & $(0.0)$ & 10 & $(10.3)$ & 50 & $(51.5)$ & 37 & $(38.1)$ \\
\hline 3 & Copable of using equipment & 46 & $(47.4)$ & 46 & $(47.4)$ & 5 & $(5.2)$ & 0 & $(0.0)$ \\
\hline 4 & Running, jumping, throwing & 0 & $(0.0)$ & 14 & $(14.4)$ & 7 & $(7.2)$ & 76 & $(78.4)$ \\
\hline 5 & Joking with other workers & 1 & $(1.0)$ & 55 & $(56.7)$ & 41 & $(42.3)$ & 0 & $(0.0)$ \\
\hline 6 & Ineffective work safety planning & 0 & $(0.0)$ & 19 & $(19.6)$ & 64 & $(66.0)$ & 19 & $(19.6)$ \\
\hline 7 & Provision of work safety equipment & 0 & $(0.0)$ & 3 & $(3.1)$ & 50 & $(51.5)$ & 44 & $(45.4)$ \\
\hline 8 & Good field arrangement & 75 & $(77.3)$ & 22 & $(22.7)$ & 0 & $(0.0)$ & 0 & $(0.0)$ \\
\hline 9 & Equipment setting & 66 & $(68.0)$ & 31 & $(32.0)$ & 0 & $(0.0)$ & 0 & $(0.0)$ \\
\hline 10 & Unfit labor equipment & 11 & $(11.3)$ & 37 & $(38.1)$ & 35 & $(36.1)$ & 14 & $(14.4)$ \\
\hline 11 & Attention to lighting, ventilation, and others & 79 & $(81.4)$ & 18 & $(18.6)$ & 0 & $(0.0)$ & 0 & $(0.0)$ \\
\hline 12 & Work according to labor & 80 & $(82.5)$ & 17 & $(17.5)$ & 0 & $(0.0)$ & 0 & $(0.0)$ \\
\hline 13 & Work according to the actual conditions & 38 & $(39.2)$ & 57 & $(58.8)$ & 2 & $(2.1)$ & 0 & $(0.0)$ \\
\hline 14 & Work in accordance with the reference of work & 35 & $(36.1)$ & 38 & $(39.2)$ & 24 & $(24.7)$ & 0 & $(0.0)$ \\
\hline 15 & High-risk jobs but no control efforts in them & 24 & $(24.7)$ & 47 & $(48.5)$ & 26 & $(26.8)$ & 0 & $(0.0)$ \\
\hline 16 & Inappropriate workload & 0 & $(0.0)$ & 26 & $(26.8)$ & 57 & $(58.8)$ & 26 & $(26.8)$ \\
\hline 17 & Mental worker & 0 & $(0.0)$ & 38 & $(39.2)$ & 13 & $(13.4)$ & 46 & $(47.4)$ \\
\hline 18 & Physical worker & 0 & $(0.0)$ & 20 & $(20.6)$ & 48 & $(49.5)$ & 29 & $(29.9)$ \\
\hline
\end{tabular}


Based on table 7, shows that from the 18 items, question number 4 is as many as $76(78.4 \%)$ respondents never perform actions such as running, jumping, throwing while working. A total of $64(66.0 \%)$ respondents to item number 1 stated that they rarely / sometimes use complete personal protective equipment while working. Question number 13 as many as $57(58.8 \%)$ respondents said the work according to the actual conditions. Also known in question item number 12 as many as $80(82.5 \%)$ respondents stated that the work they do is always in accordance with the workforce.

\section{DISCUSSION}

Adults and the elderly tend to take unsafe actions or unsafe actions so that the incidence of work accidents occurs (Pratama, 2015). Men in general do more work on direct land and do more strenuous activities than women. Work accidents in men occur due to machinery and agricultural equipment used, while women are more commonly exposed to animals such as insects that are on the ground (Jadhav, et al, 2015). Meanwhile, according to Jawawi (2008) workers with the female sex more often have work accidents when viewed from physical such as muscle ability, posture, and weaker body resistance than men.

In this study showed that most of the last level of education of tobacco farmers in Kalisat Subdistrict was elementary school. The level of education affects the mindset process of farmers to be able to receive all information in the field of agriculture. Workers who have a low education will be vulnerable to work accidents (Damayanti and Ramandhani, 2018). This statement contradicts Pratama (2015) which states that a specific job in it requires more physical skills and abilities than formal education. The study showed that more than half of the respondents worked as tobacco farmers for more than 20 years. The length of time work is related to the physical condition of the worker's body. Based on research of Damayanti and Ramandhani (2018) said most workers who experience work accidents have a working period of more than 10 years due to unsafe act and careless behavior.

The characteristics of work accidents according to the type of accident in this study are mostly hit by immovable objects. Based on research conducted by Noor, et al (2018) work accidents that most often occur in workers are hit by immovable objects that are sharp or hard. This is due to the lack of worker skills towards the use of tools or objects that result in work accidents. Researchers assume the type of equipment used by farmers can cause work accidents. This is because the majority of farmers have accidents hit by objects not moving. Therefore, the use of personal protective equipment is very important to minimize the occurrence of work accidents.

The characteristics of work accidents according to objects in this study are mostly work equipment. The use of machinery and tools needs to be considered in the agricultural sector. The condition of a piece of equipment both age and quality greatly affect the occurrence of work accidents. Old tools may be damaged. If the device has been damaged, of course it can cause an accident (Darsini, 2017). In the standard operating procedures, there are usually restrictions on equipment and safety operations, procedures to turn on, operate and turn off equipment to avoid incidents of work accidents that can occur (Sucipto, 2014).

The characteristics of work accidents according to the nature of injuries in this study are mostly mild injuries. Based on research conducted by Triyono (2016) mentioned the most common wounds in farmers, namely abrasions, bruises, torn wounds, and iris wounds. According to Sari research (2018) the most injuries experienced by farmers are open wounds as much as $52.94 \%$. Research conducted by Siregar (2018) states farmers during spraying do not use footwear or boots. Soil conditions that contain several stones and plant roots can injure the farmer's feet causing minor injuries such as abrasions on the skin of the feet.

The characteristics of work accidents according to the location of the wounds in this study are mostly injured in the hands. According to ILO (2007) as many as $26 \%$ of tobacco farmers said they had suffered hand injuries due to bamboo blades. In Muchtarom research (2017) the most injuries found on fingers or hands as many as 14 accidents in farmers. The use of hands as control holders of work equipment such as hoes, sickles, and pesticide sprayers is the cause of most often farmers experience injuries on the hands that cause injuries.

The characteristics of work accidents according to the cause in this study are mostly the lack of compliance of respondents to use personal protective equipment (PPE) in full. The use of personal protective equipment is a way that can be used by labor to protect his body from potential hazards or work accidents (Hayati et al., 2018). Research conducted by Mulyani, Sawitri, and Nadira (2018) shows that the majority of farmers in Paloh Gadeng Village do not use PPE when working, which is as many as $60(80 \%)$ farmers. The use of personal protective equipment (PPE) that is not in accordance with K3 standards can cause injury to the extremities while working. Improper use of personal protective equipment (PPE) can interfere with the health and safety of farmers' work when carrying out agricultural land processing activities (Indriana et al., 2020). 
The conclusion of this study is characteristic of tobacco farmers in Kalisat District of Jember Regency who have been willing to be respondents to this study, namely as many as $84.5 \%$ have a male gender and $15.5 \%$ have a female gender. The result of the characteristics of work accidents according to their type as many as $43.3 \%$ of tobacco farmers often experience the occurrence of hit objects not moving because they are hit by objects such as hoes, sickles, and others. The result of the characteristics of work accidents according to objects as many as $36.1 \%$ of tobacco farmers often experience accidents due to work equipment equipment caused by sharp objects. Characteristics of work accidents by the nature of injuries as many as $26.8 \%$ of tobacco farmers often experience the incidence of minor injuries and $9.3 \%$ stated that they always experience such incidents in work such as abrasions, torn wounds, iris wounds, and scratches. The result of the characteristics of work accidents according to the location of injuries as many as $36.1 \%$ of tobacco farmers often experience injuries to the upper extremities of the upper body, namely on the hands. The result of the characteristics of work accidents according to the cause is that as many as $66.0 \%$ of tobacco farmers rarely use personal protective equipment (PPE) when working.

The advice from this study to health services as a preventive and evaluation effort for health centers in the application of occupational health unit to be more optimal and become the basis of development or improvement in providing holistic nursing care services. Researchers can further develop about what are the factors that can cause work accidents and how effective ways can be done to reduce work accidents among tobacco farmers.

\section{ACKNOWLEDGEMENT}

Thanks to all respondents who have participated in this research and have been cooperative during the research.

\section{REFERENCES}

Damayanti \& Ramandhani. (2018). Gambaran Kecelakaan Kerja Di Industri Baja X Gresik Indonesia. Journal of Industrial Hygiene and Occupational Health. 2(2), 152-161

Darsini. (2017). Tingkat Kebisingan Unit Penggilingan Padi atau Gabah di Boyolali. Seminar Nasional IENACO.

Hayati, R., K. Kasman., R. Jannah. (2018). Faktor-Faktor yang Berhubungan dengan Penggunaan Alat Pelindung Diri pada Petani Pengguna Pestisida. Jurnal Kesehatan Masyarakat. 8(1).

ILO. (2007). Pekerja Anak di Industri Tembakau. Ganeva: International Labour Office.

Indriana, K.N.B., A. I. W. Suarta., I. G. A. M. Aryasih. (2020). Tingkat Pengetahuan Sikap Dan Tindakan Petani Tentang Penggunaan Alat Pelindung Diri Di Subak Cepik Kabupaten Tabanan Tahun 2019. Jurnal Kesehatan Lingkungan. 10(1), 32-41.

Intani, A. C. (2013). Hubungan Beban Kerja Dengan Stres Pada Petani Lansia Di Kelompok Tani Tembakau Kecamatan Sukowono Kabupaten Jember. Skripsi. Jember: Program Studi Ilmu Keperawatan Universitas Jember.

Jadhav R., Achutan, Haynatzki, Rajaram. (2015). Risk Fators for Agricultural Injury : A System Review and Meta Analysis. Journal of Agromedicine. 434-449.

Jawawi, I. (2008). Beberapa Faktor Risiko yang Berhubungan Dengan Tingkat Kecelakaan Kerja di PT Hok Tong Pontianak.

Lestari, D. I., R. Purwandari., A. T. Afandi. (2021). description of musculoskeletal disorder and work position in citrus farmers at Sukoreno Village Umbulsari District Jember. Jurnal IImu Keperawatan. 9(1), 20-27

Markus, S., Tien, S., Deni, W. K., Akhmad, J., Abdillah, A., Abdoel, M., Nugroho, A. P., \& Nurhadi, W. (2015). Petani Tembakau di Indonesia: Sebuah Paradoks Kehidupan. Leutikaprio.

Muchtarom, I. (2017). Analisis Risiko Keselamatan dan Kesehatan Kerja Pada Pekerja Petani Padi di Desa Metatu Kecamatan Benjeng Kabupatem Gresik. Skripsi. Surabaya: Fakultas Kesehatan Masyarakat Universitas Airlangga.

Mulyani, H. Sawitri., C. S. Nadira. (2018). Hubungan Pengetahuan dengan Pemakaian Alat Pelindung Diri (APD) pada Petani Pengguna Pestisida di Desa Paloh Gadeng Kabupaten Aceh Utara. https://www.researchgate.net/publication/342497512

Nanda, A. (2012). Perilaku Petani pada Pemakai Alat Pelindung Diri (APD) dalam Penyemprotan Pestisida di Desa Krueng Pantokecamatan Kuala Batee Kabupaten Aceh Barat Daya. Skripsi. Aceh: Program Studi IImu Kesehatan Masyarakat Universitas Teuku Umar.

Noor, R., F. Harianto., E. Susanti. (2018). Karakteristik Kecelakaan Kerja Pada Pelaksanaan Proyek Konstruksi Di Surabaya.

Padaallah, A. P., E. W. Wuryaningsih., A.T. Afandi. (2021). Description of Stress and Coping Mechanism Farmer in Kalisat District Jember Regency Indonesia. Nursing and Health Science Journal. 1(1), 54-56

Pratama. (2015). Hubungan Karakteristik Pekerja Dengan Unsafe Action Pada Tenaga Kerja Bongkar Muat Di Pt. Terminal Petikemas Surabaya. The Indonesian Journal of Occupational Safety and Health. 4(1), 64- 73

Sari, C. W. K. (2018). Kejadian dan Karakteristik Cidera pada Petani di Kecamatan Kalisat Kabupaten Jember. Skripsi. Jember: Fakultas Keperawatan Universitas Jember.

Septiani, A. S. (2019). Gambaran Distress Psikologis pada Petani Tembakau di Kecamatan Kalisat Kabupaten Jember. Skripsi. Jember: Fakultas Keperawatan Universitas Jember. 
Sucipto, C.D. (2014). Keselamatan dan Kesehatan Kerja. Jakarta: Gosyen Publishing.

Widayati, N. (2014). Kualitas Hidup Petani Lanjut Usia Dalam Perspektif Agricultural Nursing. Penelitian Dosen Pemula. Jember: Program Studi ilmu keperawatan Universitas Jember.

Yanda, P. P., Herniwanti., Makomulamin. (2020). Identifikasi dan Analisa Risiko Kecelakaan Kerja dengan Metode FMEA (Failure Mode And Effect Analysis) Pada Kelompok Tani Palas Baru Rumbai. Journal of Public Health Sciences. 9(1): 10-16.

Zhang WJ., Jiang FB., Ou JF. (2011). Global Pesticide Consumption and Pollution: With China As a Focus. Proc Int Acad Ecol Environ Sci. 56(1), 125-144. 